$\begin{array}{ll}\text { Volume } & : 04 \\ \text { Nomor } & : 03 \\ \text { Bulan } & : \text { September } \\ \text { Tahun } & : 2018 \\ \text { http } & : / / \text { jurnal.pps.ung.ac.id/index.php/AKSARA/index }\end{array}$

\title{
Penggunaan Media Audio Visual dalam Pembelajaran IPA Dengan Model Cooperative Learning Tipe NHT Pada Materi Konduktor dan Isolator Panas Di Kelas VI Dikelas VI SDN No. 84 Kota Tengah
}

\author{
Asun Ahaya \\ Guru SDN No.84 Kota Tengah \\ asunahaya@gmail.com
}

\begin{abstract}
ABSTRAK
Penelitian ini bertujuan untuk mendeskripsikan pelaksanaan pembelajaran dan hasil belajar IPA tentang Konduktor dan Isolator dengan penggunaan media audio visual dengan model Numbered Heads Together. Penelitian ini menggunakan Penelitian Tindakan Kelas (PTK) dengan dua siklus. Berdasarkan data hasil penelitian diperoleh hasil yang cukup memuaskan. Hal ini dapat dilihat ketuntasan klasikal meningkat pada siklus I menjadi $75 \%$ dengan rata-rata 68 , kemudian peningkatan yang signifikan pada siklus II menjadi $100 \%$ dengan rata-rata 82 .
\end{abstract}

\section{Kata Kunci: Media Audio Visual, Numbered Heads Together, Hasil Belajar}

\section{PENDAHULUAN}

Dalam Pasal 3 Undang-undang RI Nomor 20 tahun 2003 diungkapkan bahwa pendidikan nasional berfungsi untuk mengembangkan kemampuan dan membentuk watak serta peradaban bangsa yang bermartabat dalam rangka mencerdaskan kehidupan bangsa, yang bertujuan untuk berkembangnya potensi siswa agar menjadi manusia yang beriman dan bertaqwa kepada Tuhan Yang Maha Esa, berakhlak mulia, sehat, berilmu, cakap, kreatif, mandiri, dan menjadi warga Negara yang demokratis serta bertanggung jawab.

Hakikat pembelajaran IPA adalah kumpulan dari pengetahuan yang mengandung fakta-fakta, konsep atau prinsip-prinsip dalam proses penemuan. Dengan tujuan pembelajaran IPA mengacu kepada KTSP bahwa seorang guru harus menumbuhkan sikap peserta didik untuk bersyukur kepada ciptaan Tuhan Yang Maha Esa, menerapkan pembelajaran IPA dalam kehidupan sehari-hari, mengembangkan rasa ingin tahu terhadap sains, teknologi, dan masyarakat, memelihara serta menjaga kelestarian lingkungan. Jadi pembelajaran IPA di SD/MI menekankan pada pemberian pengalaman belajar secara langsung melalui penggunaan dan pengembangan keterampilan proses dan sikap ilmiah.

Berdasarkan pengamatan hasil belajar peserta didik yang dilakukan di SDN No.84 Kota Tengah pada hari Jum'at tanggal 10 Mei 2018, mendapatkan nilai dibawah KKM sebesar 56\%. Saat pembelajaran berlangsung tidak dapat menguasai materi secara konkrit dan mengeluarkan pendapatnya. Dari permasalahan di atas ditemukan beberapa penyebab peserta didik merasa kesulitan dalam pembelajaran IPA adalah pertama guru hanya menggunakan satu metode pembelajaran yaitu ceramah. Kedua guru tidak menggunakan media pembelajaran, sehingga peserta didik tidak bisa membayangkan konsep kerusakan lingkungan dalam kehidupan sehari-hari. Ketiga guru tidak menggunakan variasi dalam mengajar. Keempat guru hanya memberikan konsep tanpa memberikan kesempatan kepada peserta didik 


$\begin{array}{ll}\text { Volume } & : 04 \\ \text { Nomor } & : 03 \\ \text { Bulan } & : \text { September } \\ \text { Tahun } & : 2018 \\ \text { http } & : / / \text { jurnal.pps.ung.ac.id/index.php/AKSARA/index }\end{array}$

untuk menemukan sendiri. Kelima guru memberikan banyak materi pelajaran, sehingga banyak peserta didik yang tidak tuntasan.

Permasalahan yang telah dikemukakan tersebut dapat diatasi melalui kolaborasi penggunaan media audio visual dengan model cooperative learning tipe NHT (Numbered Heads Together), yang akan diaplikasikan dalam pembelajaran IPA pada materi Konduktor dan Isolator . Melalui media audio visual peserta didik dapat berpikir secara konkrit sehingga dapat menyimpulkan sendiri tentang Konduktor dan Isolator dan model Cooperative Learning tipe NHT (Numbered Heads Together) dalam proses pembelajarannya.

Berdasarkan uraian di atas, maka penulis melakukan Penelitian tindakan Kelas (PTK) dalam rangka meningkatkan kemampuan proses dan konsep terhadap pembelajaran IPA tentang Konduktor dan Isolator di SDN No.84 Kota Tengah dengan judul: "Penggunaan Media Audio Visual pada Pembelajaran IPA dengan Model cooperative learning tipe NHT (Numbered Heads Together) untuk Meningkatkan Hasil Belajar pada Materi Konduktor dan Isolator di kelas VI SDN No.84 Kota Tengah ".

Berdasarkan permasalahan di atas, penelitian ini bertujuan (1) untuk mendeskripsikan pelaksanaan pembelajaran IPA tentang Konduktor dan Isolator melalui penggunaan media audio visual dengan model cooverative learning tipe NHT (Numbered Head Together) di kelas VI SDN No.84 Kota Tengah, (2) untuk mendeskripsikan hasil belajar peserta didik dalam pembelajaran IPA tentang Konduktor dan Isolator melalui penggunaan media audio visual dengan model cooperative learning tipe NHT (Numbered Head Together) di kelas VI SDN No.84 Kota Tengah.

\section{METODE PENELITIAN}

Adapun jenis penelitian yang dilakukan dalam penelitian ini adalah penelitian tindakan kelas (PTK). Menurut McNiff dalam bukunya yang berjudul Action Research Principles and Practice memandang PTK sebagai bentuk penelitian reflektif yang dilakukan oleh pendidik sendiri terhadap kurikulum, pengembangan sekolah, meningkatkan perstasibelajar, pengembangan keahlian mengajar, dan sebagainya.

Penelitian yang dilakukan oleh guru di kelas atau di sekolah tempat mengajar dengan penekanan pada penyempurnaan atau peningkatan praktik dan proses dalam penelitian sendiri. Menurut Mulyasa penelitian tindakan kelas selalu berhubungan dengan data kuantitatif dan kualitatif, baik yang menyangkut aktivitas dan kreatifitas siswa, maupun kinerja guru dalam pembelajaran. Data kuantitatif berupa angka-angka tentang hasil belajar siswa, sedangkan data kualitatif adalah ungkapan yang mengekspresikan siswa tentang hasil belajar yang diperolehnya (senang, tidak senang, paham, kurang paham dan seterusnya.

Sesuai jenis penelitian yang dipilih yaitu penelitian tindakan kelas, maka penelitian ini menggunakan penelitian tindakan kelas model spiral Kemmis dan Taggart yaitu terbentuk sepiral dari siklus yang satu ke siklus yang berikutnya. Model Kemmis dan Taggart merupakan pengembangan dari konsep dasar yang diperkenalkan Kurt Lewin, hanya saja komponen acting dan observing dijadikan satu kesatuan karena keduanya merupakan tindakan yang tidak terpisahkan, terjadi 
dalam waktu yang sama. Dalam perencanaannya Kemmis menggunakan sistem sepiral refleksi diri yang setiap siklus meliputi rencana (planning), tindakan (acting), pengamatan (observing), dan refleksi (reflecting). Langkah pada siklus berikutnya adalah perencanaan yang sudah direvisi dari siklus sepiral tahap-tahap penelitian tindakan kelas dapat dilihat pada gambar berikut:

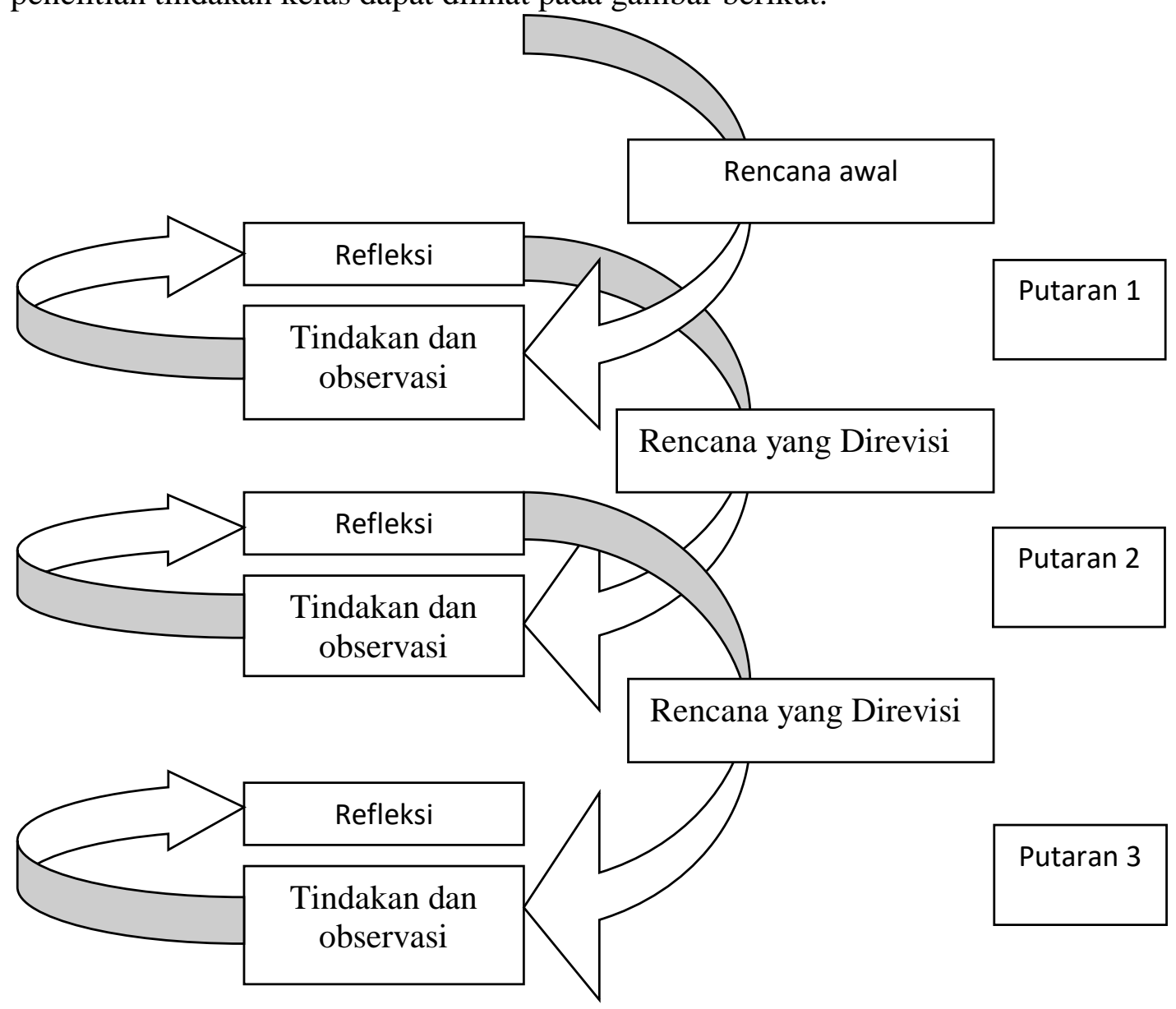

Gambar 3.1 Alur PTK Model Spiral Kemmis \& Taggart

Penjelasan alur diatas adalah :

1. Rancangan atau rencana awal, sebelum mengadakan penelitian peneliti menyusun rumusan masalah, tujuan dan membuat rencana tindakan, termasuk didalamnya instrumen penelitian dan rancangan pembelajaran.

2. Kegiatan dan pengamatan, meliputi tindakan yang dilakukan oleh para peneliti sebagai upaya membangun pemahaman, siswa serta mengamati hasil atau dampak dari diterapkannya model pembelajaran ini.

3. Refleksi, para peneliti mengkaji, melihat dan mempertimbangkan hasil atau dampak dari tindakan yang dilakukan berdasarkan lembar pengamatan yang diisi oleh pengamat.

Rencana yang direvisi, berdasar hasil refleksi pengamat membuat rencana yang direvisi untuk dilaksanakan pada siklus berikutnya 
Adapun proses pengumpulan data adalah sesuai dengan tujuan penelitian, proses pengumpulan data diperoleh melalui: evaluasi, observasi dan dokumentasi. Untuk evaluasi pembelajaran dilakukan dengan dua cara. Pertama melalui LKPD dan cara post tes di akhir pembelajaran. Tes yang digunakan dalam penelitian ini adalah tes essay. Menurut Purwanto (1984:35) "tes essay adalah tes yang berbentuk pertanyaan tulisan, yang jawabanya merupakan karangan atau kalimat yang panjang-panjang". Kedua observasi yang dilakukan oleh peneliti melalui pengamatan dan mencatat kejadian penting dalam proses pembelajaran IPA tentang Konduktor dan Isolator. Sebelum melaksanakan observasi peneliti menyiapkan lembar observasi sesuai dengan apa yang akan diamati, kemudian mendiskusikan lembar observasi bersama observer.

\section{HASIL PENELITIAN DAN PEMBAHASAN}

Deskripsi Kondisi Awal

Masalah yang dialami oleh siswa kelas V SDN No.84 Kota Tengah semester 1 Tahun Pelajaran 2017/2018 dalam IPA adalah rendahnya Hasil belajar konsep Konduktor dan Isolator siswa dalam pembelajaran IPA. Hal tersebut terlihat dari nilai siswa yang rendah pada nilai tes tertulis maupun nilai praktik. Untuk lebih jelasnya dapat dilihat pada table dan grafik berikut.

Tabel Hasil belajar Siswa pada Kondisi Awal

$$
\text { Uraian }
$$

Nilai rata-rata

Nilai tertinggi

Nilai terendah

KKM

\section{Nilai Praktek}

61,9

70

50

71

Ketuntasan

0 siswa $(0 \%)$

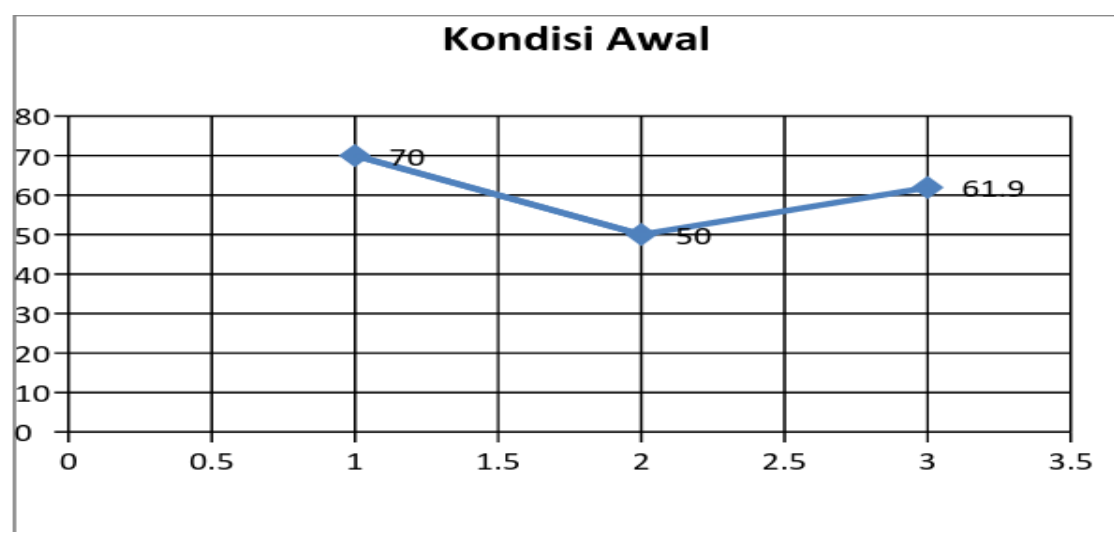

Gambar Hasil belajar Siswa pada Kondisi Awal

Dari data di atas, pada kondisi awal ini nilai rata-rata siswa hanya 61,9, jauh di bawah nilai Kriteria Ketuntasan Minimal (KKM) yang ditetapkan dalam pembelajaran IPA di SDN No.84 Kota Tengah, yaitu 70, siswa yang mencapai KKM tidak ada atau 0 siswa atau \% dari total 21 siswa kelas VI. Ada 2 faktor yang menyebabkan rendahnya hasil belajar konsep Konduktor dan Isolator pada siswa dalam pembelajaran IPA rendah pada siswa kelas V SDN No.84 Kota Tengah, yaitu 


$\begin{array}{ll}\text { Volume } & : 04 \\ \text { Nomor } & : 03 \\ \text { Bulan } & : \text { September } \\ \text { Tahun } & : 2018 \\ \text { http } & : / / \text { jurnal.pps.ung.ac.id/index.php/AKSARA/index }\end{array}$

faktor internal dan faktor eksternal. Faktor internal siswa tersebut antara lain: motivasi, intelegensi, kebiasaan dan rasa percaya diri. Sedangkan faktor eksternal adalah faktor yang terdapat di luar siswa, seperti; guru sebagai pembina kegiatan belajar, startegi pembelajaran, sarana dan prasarana, kurikulum dan lingkungan.

Pada pembelajaran IPA selama ini masih menggunakan metode pembelajaran yang monoton, yaitu ceramah dan instruksi langsung. Dengan metode ini membuat siswa kurang aktif, hanya guru yang aktif menyampaikan materi. Dan berdasarkan hasil pengamatan dan pengalaman selama ini, siswa kurang aktif dalam kegiatan belajar-mengajar. Anak cenderung tidak tertarik dengan pelajaran IPA sehingga menyebabkan rendahnya Hasil belajar siswa di sekolah.

Untuk mengatasi masalah tersebut, peneliti sekaligus sebagai guru IPA akan melaksanakan suatu penelitian tindakan kelas dengan menerapkan metode NHT dan media Audio Visual. Diharapkan melalui penelitian tindakan kelas ini dapat meningkatkan hasil belajar konsep Konduktor dan Isolator pada siswa dalam pembelajaran IPA pada siswa kelas VI SDN No.84 Kota Tengah.

\section{Deskripsi Hasil Siklus I}

Hasil pengamatan pada siklus I pertemuan pertama dilaksanakan, banyak siswa terlihat belum aktif dan canggung karena siswa belum terbiasa menerapka metode NHT dan media Audio Visual, serta beberapa siswa yang kurang fokus dalam pembelajaran. Setelah guru memberi motivasi, siswa mengikuti pelajaran dengan baik. Meskipun demikian, motivasi siswa dalam menerima penjelasan guru masih cukup tinggi. Siswa saling membantu dan bekerjasama dengan temannya, yang diam dan pasif terus berupaya untuk bisa. Demikian upaya guru dalam memotivasi para siswa. Ternyata upaya ini cukup berhasil, siswa berusaha untuk aktif dalam mengikuti pelajaran IPA.Dan hasil tes hasil belajar maupun tes tertulis materi Konduktor dan Isolator pada siswa kelas VI adalah sebagai berikut:

Tabel Hasil Belajar Siswa pada Siklus I

Uraian

Nilai tertinggi

Nilai terendah

Nilai rata-rata

KKM

Ketuntasan
Nilai Praktek

80

60

68,8

71

6 siswa $(28,5 \%)$ 


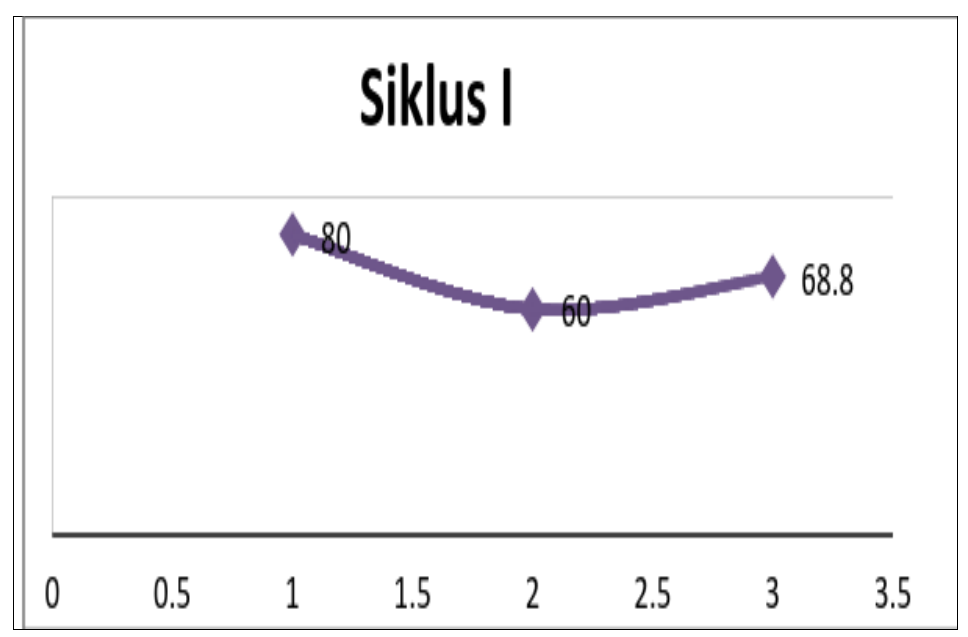

Gambar hasil belajar Siswa pada Siklus I

Melalui penerapan media gambar pada siklus I, nilai rata-rata hasil belajar siswa adalah 68,8 nilai tertinggi 80 dan nilai terendah adalah 60. Sedangkan jumlah siswa yang mencapai nilai KKM sejumlah 6 siswa $(28,5 \%)$ dari total 21 siswa kelas VI SDN No.84 Kota Tengah semester I Tahun Pelajaran 2017/2018.Refleksi hasil implementasi penerapan Metode NHT dan media Audio Visual pada siklus I adalah sebagai berikut,

Uraian

Tindakan

Nilai tertinggi

Nilai terendah

Nilai rata-rata
Kondisi Awal

Belum menerapkan media gambar dalam pembelajaran IPA.

70

50

$$
61,9
$$

Siklus I

Sudah menerapkan dan media pembelajaran IPA

80

60

68,8

6 siswa $(28,5 \%)$

Dari tabel di atas diperoleh fakta bahwa Hasil belajar konsep Konduktor dan Isolator pada siswa dalam pembelajaran IPA siswa pada kondisi awal sebelum pelaksanaan tindakan, nilai rata-ratanya adalah 61,9 (jauh di bawah nilai KKM), nilai tertinggi 70, nilai terendah 50 dan hanya 0 siswa $(0 \%)$ yang mencapai nilai KKM atau tidak ada siswa yang mencapai KKM. Pada siklus I, melalui metode diskusi kelompok terarah dan media gambar, hasil belajar siswa menunjukkan peningkatan. Nilai rata-rata siswa menjadi 68,8 (masih di bawah nilai KKM), nilai tertinggi 80 , nilai terendah 60 dan siswa yang mencapai ketuntasan KKM sejumlah 6 siswa $(28,5 \%)$.

Meskipun terjadi peningkatan pada siklus I ini, namun peningkatannya belum mencapai indikator keberhasilan dalam penelitan ini. Maka peneliti dan guru kolaborator memutuskan untuk melanjutkan tindakan penelitian ke siklus II dengan tetap menerapkan metode NHT dan media Audio Visual, dengan perbaikan pada kelemahan dan kekurangan yang terjadi di siklus I.

Deskripsi Hasil Siklus II

Berdasarkan pengamatan yang dilakukan oleh guru kolaborator, pada siklus II ini siswa menunjukkan peningkatan dibandingkan siklus I. Pada kegiatan pembelajaran siklus II, secara umum siswa dapat dengan baik memahami metri Konduktor dan Isolator. Siswa juga tampak semakin semakin percaya diri, hal ini 
karena siswa telah melaksanakan diskusi dengan teman tim sebelumnya. Bila dibandingkan dengan penampilan kegiatan pembelajaran pada siklus I, interaksi siswa lebih baik. Hasil Belajar siswa pada siklus II dapat dilihat sebagai berikut

Tabel Hasil Belajar Siswa pada Siklus II

Uraian

Nilai tertinggi

Nilai terendah

Nilai rata-rata

KKM
Nilai Praktek

85

70

76,9

71

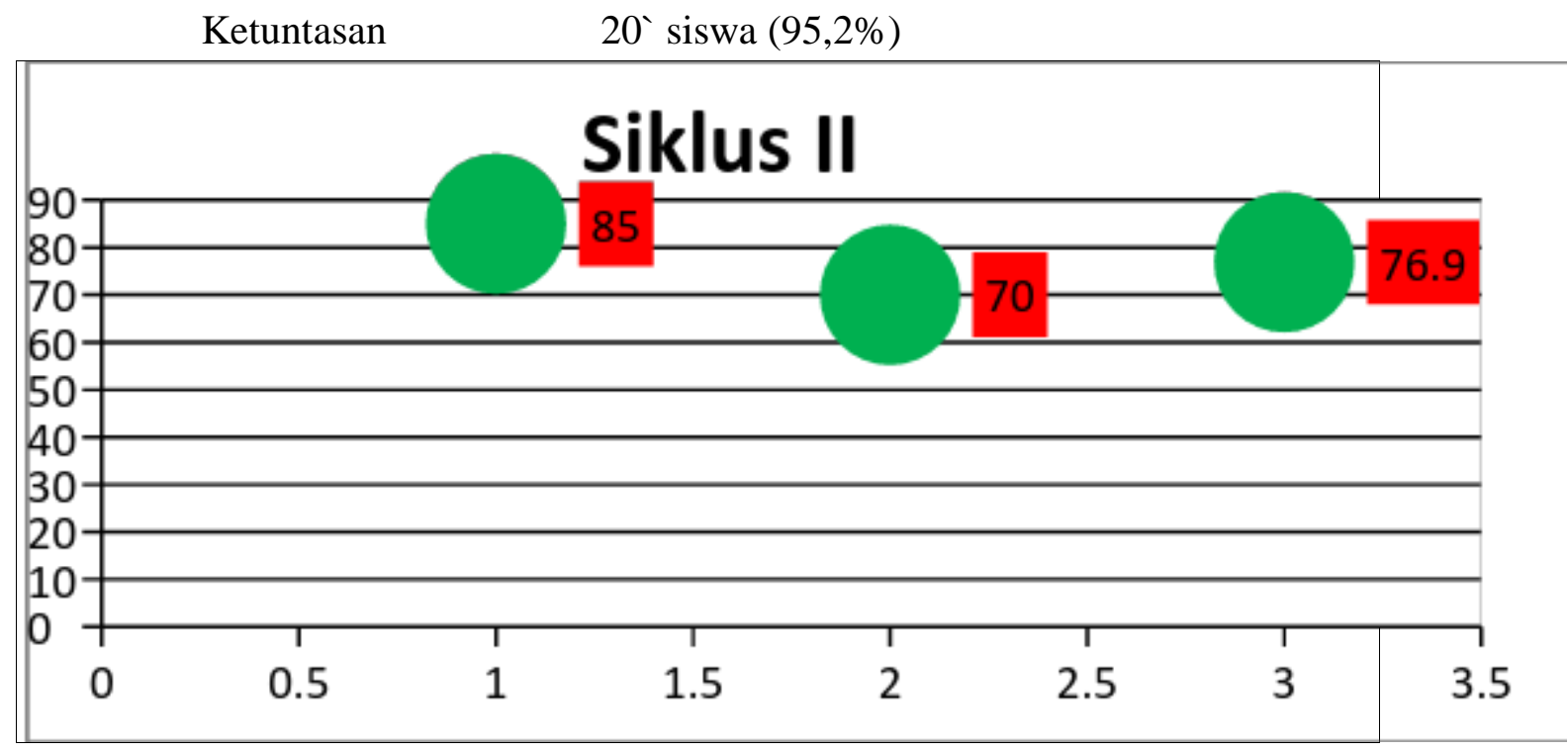

Gambar Hasil Belajar Siswa pada Siklus II

Nilai rata-rata Hasil Belajar konsep Konduktor dan Isolator siswa VI SDN No.84 Kota Tengah pada siklus II adalah 76,9 (di atas nilai KKM), nilai tertinggi 85, nilai terendah 70 dan siswa yang berhasil mencapai nilai KKM sebanyak 20 siswa $(95,2 \%)$, berarti ada 1 siswa yang nilainya di bawah KKM. Peningkatan Hasil Belajar konsep Konduktor dan Isolator siswa kelas VI SDN No.84 Kota Tengah pada siklus II jika dibandingkan siklus I adalah sebagai berikut,

Uraian

Tindakan

Nilai tertinggi

Nilai terendah

Nilai rata-rata

Ketuntasan
Siklus I

Sudah menerapkan media dalam pembelajaran IPA.

80

60

68,8

Siklus II

Sudah menerapkan media dalam pembelajaran IPA.

$$
\begin{gathered}
85 \\
70 \\
76,9
\end{gathered}
$$

6 siswa $(28,5 \%)$

Dari tabel di atas, secara empiris diperoleh fakta bahwa Hasil belajar konsep Konduktor dan Isolator siswa setelah pelaksanaan tindakan penelitian siklus II melalui penerapan metode NHT dan media Audio Visual menunjukkan peningkatan daripada siklus I. Pada siklus I, nilai rata-rata Hasil belajar 


$\begin{array}{ll}\text { Volume } & : 04 \\ \text { Nomor } & : 03 \\ \text { Bulan } & : \text { September } \\ \text { Tahun } & : 2018 \\ \text { http } & : / / \text { jurnal.pps.ung.ac.id/index.php/AKSARA/index }\end{array}$

konsep Konduktor dan Isolator siswa kelas VI adalah 68,8 (di bawah nilai KKM), nilai tertinggi 80, nilai terendah 60 dan siswa yang mencapai ketuntasan KKM sejumlah 6 siswa (28,5\%).Pada siklus II Hasil belajar konsep Konduktor dan Isolator siswa kelas $\mathrm{V}$ menunjukkan peningkatan, menjadi nilai rata-rata 76,9 (di atas nilai KKM), nilai tertinggi 85, nilai terendah 70 dan siswa yang mencapai nilai KKM menjadi 20 siswa $(95,2 \%)$, berarti tidak ada siswa yang nilainya di bawah KKM.

Peningkatan hasil belajar konsep Konduktor dan Isolator siswa kelas VI SDN No.84 Kota Tengah semester I Tahun Pelajaran 2017/2018 pada siklus II sudah mencapai indikator keberhasilan dalam penelitan tindakan kelas ini. Akan tetapi peneliti dan guru kolaborator memutuskan untuk menghentikan tindakan penelitian ini ke siklus berikutnya untuk melihat kevalidan efektivitas metode diskusi kelompok terarah dan media gambar dalam meningkatkan hasil belajar siswa. Jadi melalui penerapan media Visual dapat meningkatkan hasil belajar konsep Konduktor dan Isolator pada siswa kelas V SDN No.84 Kota Tengah Tahun Pelajaran 2017/2018.

\section{SIMPULAN}

Setelah dilaksanakan penelitian tindakan kelas melalui penerapan Metode NHT dan media Audio Visual dalam 2 (dua) siklus, diperoleh hasil sebagai berikut: Hipotesis menyatakan: diduga melalui penerapan Metode NHT dan media Audio Visual dapat meningkatkan Hasil belajar materi Konduktor dan Isolator pada siswa kelas VI SDN No.84 Kota Tengah Tahun Pelajaran 2017/2018.

Data empiris menyatakan bahwa melalui penerapan Metode NHT dan media Audio Visual dapat meningkatkan hasil belajar konsep Konduktor dan Isolator pada siswa kelas VI dalam pembelajaran IPA dari kondisi awal nilai rata-rata siswa 61,9 dengan siswa yang mencapai ketuntasan KKM sejumlah 0 siswa (0\%) ke kondisi akhir nilai rata-rata 76,9 dengan siswa yang mencapai ketuntasan KKM sejumlah 20 siswa $(95,2 \%)$ pada siswa kelas V SDN No.84 Kota Tengah semester I Tahun Pelajaran 2017/2018.

\section{DAFTAR PUSTAKA}

Andayani, dkk. (2007). Pemantapan Kemampuan Profesional. Jakarta: Pusat Penerbitan Universitas Terbuka.

Nur Herrhyanto dan Akib Hamid. (2004). Statistik Dasar. Jakarta: Universitas Terbuka.

Prayitno, Eman Anti. Dasar-dasar Bimbingan dan Konseling. Jakarta: Proyek.

Suparno dan Muhammad Yunus. (2003). Ketrampilan Dasar Menulis. Jakarta: Pusat Penerbitan Universitas Terbuka.

Tabrani Rusyan, Atang Kusdinar \& Zainal Arifin, 1992, Pendekatan dalam Proses Mengajar, Bandung: Remaja Karya.

Wardani, I.G.K., Siti Julaeha dan Ngadi Marsinah. Pemantapan Kemampuan Profesional. Jakarta: Universitas Terbuka.

Wardani, I.G.K., Kuswoyo Wihardit, dan Noehi Nasoetion, (2003). Penelitian Tindakan Kelas. Jakarta: Universitas Terbuka. 